(c) $2018 \mathrm{Dr}$. Olga Matthias. This is an open access article licensed under the Creative Commons AttributionNonCommercial-NoDerivs License (http://creativecommons.org/licenses/by-nc-nd/3.0/).

\title{
The 'World's Newest Profession' is no Longer Dispensable; What Does it Mean for Consultancy Firms?
}

\author{
Dr Olga Matthias, Sheffield Business School
}

\begin{abstract}
A major focus for consultants is pipeline. Generating future work is as important as delivering current projects because it provides continuity and hopefully growth of the business. This inherent uncertainty in the sales pipeline is perhaps the consulting firms' biggest concerns. This paper seeks to demonstrate how management consultancy has actually become widespread and embedded in the economic activity of organisations. The research synthesised in this paper presents client perspectives on how consultants add value. Particular insight is given into the key features which differentiate those firms that are chosen for projects against those that are not. The findings suggest that the industry has transitioned from a dispensable service to an institutionalised one, embedded in client business cycles and operating procedures. This has implications for how individual consultancy firms develop and deliver their services, moving emphasis from market uncertainty to service design and quality.
\end{abstract}




\section{Introduction}

The research presented in this paper provides a client perspective into an industry which permeates modern corporations and strongly influences their economic performance, and arguably the global economy. The paper outlines the decision-making sequences, the operational processes and the institutional influences involved in the engagement of management consultants. In doing so, the research demonstrates how clients maximise management value by establishing consultants as a cornerstone of management decision-making, embedded in organisational contexts, influencing and influenced by institutional norms.

From its beginnings in early twentieth century America, the management consulting industry has evolved to become a worldwide phenomenon. Kennedy (2010) has estimated that in 1975 the worldwide consulting market was $\$ 4.8 \mathrm{bn}$ and had grown to $\$ 305$ bn by 2012 (Marketline, 2013), showing 13,000\% worldwide revenue growth without inflation correction (Plunkett, 2014). The UK consulting industry is worth around $£ 12 \mathrm{bn}$ and employs more than 80,000 consultants (loC, 2017). Despite these figures, Management Consultancy is an industry beleaguered by contradictions and prejudices (Ernst and Kieser, 2000), remains a mystery to most outsiders (Buono, 2015), and is perceived negatively, fuelled by publications such as Kinn (2005), Craig and Brooks (2006) and Kirkpatrick et al. (2018). Reinforced by regular bad press (Hari, 2010, Economist, 2013, Hope, 2016, Gapper, 2017) the consultancy industry is regarded warily. Such views do not align with the plain economic fact that consultancy growth, as in any service industry, hinges on client satisfaction.

This research seeks to understand what makes for good consulting, how clients decide who the good consultants are for given assignments, and what, if anything, this means for consultancy firms. Consequently, questions regarding management consulting services arise. They are:

(RQ1) How do clients define good service?

(RQ2) What makes clients choose who they choose?

The research questions are answered through primary data from interviews with 60 people across 16 global utilities and financial services firms, being the largest buyers of consultancy services (Marketline, 2016). Semi-structured interviews provide context and depth of information. The analysis is interpretive and provides an industry-wide perspective of what drives client behaviour and how the findings are useful for consulting firms. Historical context, which lays the foundation for the empirical analysis, is provided by an examination of secondary sources including historical data.

\section{The Emergence and Growth of the Consulting Industry}

Advisors have existed throughout history, providing the rich and powerful with advice, nominally independent and sometimes strategic (Schein, 1999, Furusten, 2013, O'Mahoney and Markham, 2013). Consultancy has been described as 'The creation of value for organizations - through improved performance, achieved by providing 
objective advice and implementing business solutions' (MCA, 2017) and 'a point of reference and a source of innovation for organisations and institutions across Europe' (FEACO, 2017:4).

Three strands of value creation and innovation converged in the first half of the twentieth century to create the modern management consulting industry (Kipping and Engwall, 2002). Taylor (1911) pioneered what became known as Scientific Management which was expanded by Gantt, Emerson, Bedaux and others. Firms such as Arthur D Little arose from collaboration between large companies and leading engineering universities, examples being AT\&T, Du Pont, GE, and Standard Oil, with Carnegie Mellon, MIT, and Stanford (Panetti, 2007). Collaborations expanded from technical to managerial, and firms became transmitters of managerial ideas developed in myriad organizational settings (Kipping, 2002, McKenna, 2006).

Accounting firms expanded their work from monitoring costs through cost-accounting to lowering costs through work study, technological developments, and any other managerial technique, laying the foundations for the corporate governance infrastructure in existence today (McKenna, 2006). In the second half of the century another new consulting market was created. When GE engaged Arthur Anderson in 1953 (Osborn, 1956) to oversee the installation of the first computer used specifically for business, the IT consulting industry was born.

These foundations have embedded the industry in the economic activity of organisations. Clients continue to use management consulting firms for a broad range of services, from help in articulating strategies to implementing large-scale IT and operational change programmes. Figure 1 shows the UK management consulting market in 2017, which generated fees of $\$ 13,752.2 \mathrm{~m}$ (Marketline, 2018). The largest spend is on Operations Management, showing clients' continued focus on dealing with immediate operational/business challenges with economic impact, and remaining true to the first two founding strands of the industry.

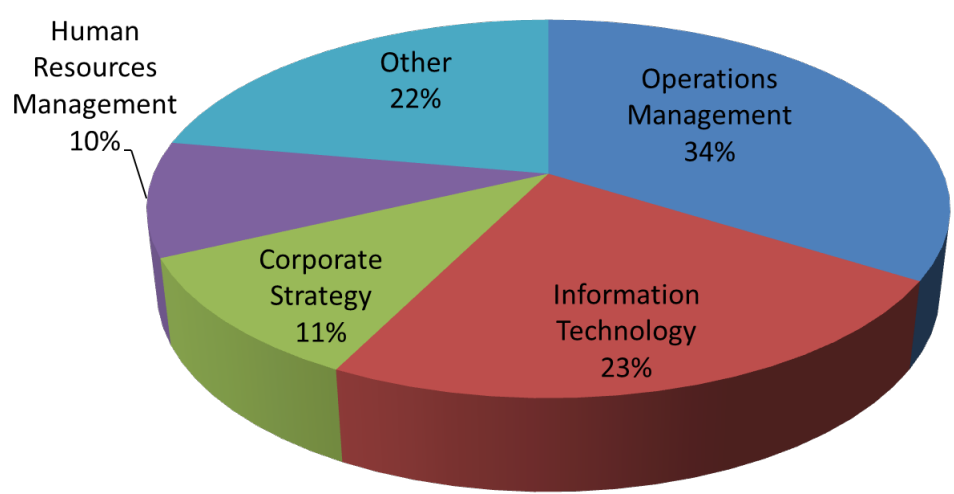

Figure 1: United Kingdom management \& marketing consultancy market category segmentation: \% share, by value, 2017 (Marketline, 2018) 


\section{Academia and Consulting}

By the 1990s the study of management consulting was attracting academic attention (Dawes et al., 1991, Alvesson, 1993, Sturdy, 1996, Clark and Salaman, 1998, de Burgundy, 1998, De Jong and Van Eekelen, 1999). Consultants' contributions to organisations' success provided a rich stream of research, largely focused on interactions with clients and the structuring and dissemination of consultant knowledge. 'Critical' perspectives became widespread, presenting consulting as systems of persuasion, rhetoric, and performance (Berglund and Werr, 2000, Ernst and Kieser, 2000, Clark and Greatbatch, 2002, Fincham, 2002, Kieser, 2002, Clegg et al., 2004, Johansson, 2004, Sturdy et al., 2006, Kitay and Wright, 2007).

There were also specific insights into the operations of consulting. Sturdy noted that when choosing consultants, clients tend to be ambivalent, both positive and critical, of the service (1997:402). Armbruster (2006) observed that consultants provide advice on demand-intensive issues which are not people-specific, making them outsourceable. Malhotra and Morris (2009) reflected that clients require customised solutions which take the form of intangible applications of complex knowledge. Muzio et al. (2010) opined, not unreasonably given the fees generated, that consulting services are costly.

\section{Inherent Complexities of Buying Consulting Services}

The nature of consulting is fluid since intangible applications of complex knowledge make reconfiguration possibilities infinite. Judging its performance and quality therefore is difficult and open to multiple interpretations (Ernst and Kieser, 2000, Lowendahl et al., 2001, Hill et al., 2009, Sturdy, 2011). Another complication is that without legislative compulsion to purchase, consulting is a dispensable, discretionary service, commissioned on an ad hoc basis (Patterson, 2000, Armbrüster and Glückler, 2007). Clients might choose to use internal capabilities, do nothing or reject one firm in favour of another (Kitay and Wright, 2007, Sturdy et al., 2013).

Given the exponential rise in fee-generation since the industry's inception, it appears that 'doing nothing' is rarely the favoured client option, certainly not in the longer term. In order to understand what tangible and intangible requirements clients have of their consultants, a client perspective was sought. Concepts of 'Ways of Knowing' (WOK), 'Ways of Working' (WOW) and 'Ways of Being' (WOB) emerged. When successfully combined, they present a well-fitting customised package to prospective clients and are a key outcome of this research.

\section{Research Method}

In order to answer the research questions set out in the introduction, semi-structured interviews were used for data collection. Senior executives who had experience of buying consultancy services were purposively approached. Asking them to reach out to others in their organisation, or colleagues who had moved to other organisations, the final participant count snowballed to sixty people representing sixteen companies. The 
participant role profile was 50 Directors/Heads of Function - 7 were manager level, and 3 were leaders (2 Chief Executives and a Chairman).

Participants were asked questions covering the following areas: what they looked for and expected from their consultants, and how they decided who they would work with. Individuals were anonymised by industry and company. Interviews were recorded and transcribed when all had been completed. Data analysis was carried out using NVivo software for capture and coding.

A 'grounded-theory lite' approach was adopted for the thematic analysis, as advocated by Braun and Clarke (2006). Interestingly, the first 6 interviews provided $80 \%$ of the codes. Saturation was therefore achieved at the halfway point, adding to the generalisability of the insights as well as robustness.

\section{Findings}

The findings presented cover the key features from the interviews and address the two research questions. The interviewees all provided similar, business-embedded explanations about the value consultants brought to their organisation (Table 1), making the choices who and how, not whether or why.

Table 1: Why companies buy consultants

\begin{tabular}{|l|l|l|}
\hline Reason & Definition & Responses \\
\hline Expertise & $\begin{array}{l}\text { looking for knowledge you do not possess, be it } \\
\text { "knowing-how" or "knowing-what" }\end{array}$ & $36 \%$ \\
\hline Externality & $\begin{array}{l}\text { looking for an external perspective, be it geography } \\
\text { or industry }\end{array}$ & $25 \%$ \\
\hline Extension & looking for an injection of extra resource & $24 \%$ \\
\hline
\end{tabular}

'Time compression economies' of speed and quality were reported as important factors, because 'it doesn't make commercial sense to have that kind of skill in permanently'. Views and insights from competitors or other industries are a useful input, bringing 'external benchmarking experience and know-how into different organisations'. An 'extra pair of hands' was a frequent consideration too, enabling ring-fencing of internal resource for 'commercial top priority' activities while consultants 'backfill the business as-usual side of activity to free up internal staff'.

The 'take your watch to tell you the time' apocryphal perspective of money-grabbing consultants is seen as independent assurance rather than a charlatan activity, whether for internal or external purposes: 'if you're paying people to come in they [the Board] tend to listen more'. Respondents were open about the scapegoating aspect or de- 
personalising of an unpleasant or difficult course of action. An alternative, 'dark side' to buying consultancy also emerged: 'for managers with fat budgets and limited capabilities, consultants are obviously quite an attractive option', on the lines of a comfort blanket or an addiction, where the removal of the habit becomes almost unthinkable.

\section{Good Consulting Service}

There were common themes regarding quality and service. Good service is unequivocally about delivering what was promised, regardless of what is actually in the contract. There is a taken-for-granted expectation that consultants are highly educated and have the expertise to deliver what is needed. This reflects a common acceptance that consultants are acknowledged as expert in collecting and codifying knowledge and applying it appropriately. External perspective is important but is over-ridden by sector and company-specific content expertise which clients expect to be transferred to the business:

"What I want and what I expect now is to look outside of our sector and think 'what's happened in telecoms, what's happening in'... UPS and TNT and all the delivery firms... Our expectation now is we've got to look out of industry and we expect those guys to do that for us, you know, and bring it in."

This aspect of consultant knowledge and the ability to apply it was labelled 'ways of knowing' (WOK), also linked to the firm and its way of codifying knowledge for subsequent dissemination and reuse.

Other taken-for-granted features are that the consultant is a hard worker, available, highly accommodating, and goes the extra mile. They are also serious, knowledgeable and fun:

"I want the perfect person. I want the person l'd have a laugh with. I want the person to be serious and deliver and drive it really hard. I don't want it to be because we're paying the bill. I want it because they enjoy what they're doing, and they get a buzz out of delivering real value."

"You're buying high-calibre individuals, top-notch people, who can deliver really outstanding excellence in every aspect of everything that they do...down to the way that the people look...the way they speak, ... present themselves... and the team... And we also look for excellence in work."

"High commitment, rapid dissimilation when they get on the ground, you know, coming in effectively, very quickly, good communication and to have the level of proficiency that they've declared in the sales process."

This needs flexibility and a strong work ethic to ensure responsiveness in the form of 'get on and do it', independence, empathy, tenacity and task-focus. Decisiveness and 
integrity are key and should also result in challenging client thinking. This was labelled 'ways of working' (WOW).

\section{What Makes Clients Choose Who They Choose?}

There is a mechanical, process aspect to purchasing and a personal, intuitive one. The mechanical process takes place in two stages. Procurement is the first, longer-term, stage. Framework agreements are established over a fixed planning-cycle of usually 5 years, to comply up-front with European Procurement Directives legislating for open and transparent procurement practices for regulated and public sector organisations. An expensive, time-consuming process taking from 4-6 months, the benefit is a list of prequalified suppliers (PSL) with a broad set of skills available at an already agreed rate. The second stage is the actual buying. It involves approaching selected companies from the PSL with a defined requirement and a request for proposal (RFP). The buying team, composed of departmental subject specialists and buying specialists, embarks on the decision-making process, sifting through proposals and subsequent presentations.

The mechanical choosing of the successful firm is based on weighted criteria, typically incorporating cost, people, and experience. The actual choosing is about 'gut feel', a sense they could work with the individual consultants:

"It's difficult to describe the cultural stuff about how they work and how they would work with us and I think that's quite a big piece and it's not always easy to articulate." "It's a heart-over-head call."

Not that the decision process is irrational but more that the 'branded firms' are difficult to differentiate between, so choice is shaped by connections which resonate and enthuse, expressed as 'chemistry' and 'gut feel'.

"Ultimately consultancies are people, so whether it's a blue-chip top five or a mid-range firm l've still had examples of good people within them and bad ones, and part of the client role is to know the difference."

What really matters is when consultants offer "a marriage of convenience rather than a marriage of intent." This was labelled 'ways of being' (WOB).

\section{Discussion}

Management consultancy has evolved significantly since its modern-day inception. Previous research suggested clients have little if any experience in buying consultancy services. The generally accepted view was that consultancy is infrequently commissioned, relatively discrete and of an ad hoc nature (Armbrüster and Glückler, 2007, Sturdy et al., 2013). When consultancy was bought, it was because clients had fallen under the spell of storytelling by gurus adept at impression management (Clark and Greatbatch, 2002, Johansson, 2004, Kitay and Wright, 2007). The findings from this research refute that. They indicate consultancy is embedded in client organisations and 
that clients buy pragmatically. Consultants are used for short-term, specific operational input (Figure 1), for specific reasons (Table 1). This confirms that choosing consultants is focused and results-oriented, rather than ambivalent (Sturdy, 1997). $60 \%$ of the respondents indicated consultants were needed because their organisation did not have the manpower or the specific knowledge to carry out a required task. This highlights the continued specialisation of labour in the economy as a whole, as begun by Taylor in the 1900s, and identifies consultants as 'agents' of management (Fincham, 2002).

The effective application of knowledge garnered from multiple industries, rapidly disseminated using proprietary tools, techniques and competencies is the depiction of the successful consultant. Consultants provide structured exploration of ideas within their own and client workplaces. This is ways of knowing (WOK). Ways of working (WOW) represents the customization of the knowledge offer with the social dimension that promotes partnership, collaboration and fit of working style. Ethos, trust and an expectation of comradeship and enjoyment is crucial to winning business, and is labelled ways of being (WOB). Successful blending of structured social and organisational activities (Sturdy et al., 2006) remains core.

Further evidence pointing to the industry's institutionalisation is found in how consulting services have become embedded in client routines by nature of clients' procurement, planning and purchasing processes. An infrastructure for formalised cyclical procurement practices exists. The framework process highlights the long-term thinking driving the use of consultants and how their engagement is now part of 'business-asusual'. The buying process reflects how consultant input permeates organisational thinking, making consulting only nominally a discretionary service. Consultancy spend forms part of the annual budgeting cycle as well as for ad hoc business issues.

\section{Conclusion}

This paper set out to answer two questions:

(RQ1) How do clients define good service?

(RQ2) What makes clients choose who they choose?

This study identified three essential 'soft' components that must be in the service offering for it to be successful. These were Ways of Knowing (WOK), Ways of Working (WOW) and Ways of Being (WOB). These respectively represent the knowledge management processes so effectively developed in all successful consultancies (WOK), and largely taken-for granted by clients; the need for both client and consultant to recognise in each other common approaches and processes that will not clash and will facilitate effective collaboration (WOW); and that intangible 'gut feeling' that they share common values, have chemistry to work together well and will go the extra mile (WOB). The analysis has shown how management consultancy has become institutionalised in client routines through formalised purchasing. Whilst this may erode ad hoc projects, it increases security of pipeline for consultancies. Questions are about what is bought, when, and from whom, rather than whether to buy. Uncertainty remains because no consulting firm is guaranteed to win any particular contract. Client choice may appear 
less dependent on relationships than previously, but it is still predicated on 'gut feel' informing service experience and people evaluation. For consultancies this should fuel creativity, perpetuate the advancement of new ideas and further insights to be safely tested and shared with clients. The combination of historical and current perspectives of consulting presented in this paper contributes to a deeper understanding of how management consultancy has developed and why it continues to thrive. Consultancy is a 'must-have' service even without statutory requirement. The empirical research highlights that despite a generally critical stance in principle, in practice clients see consultants' contributions as necessary and supportive to their overall goals. Purchasing, previously based on what could have been described as 'old-boy networks' is now transparently focused on more objective performance contribution to business success. However, the personal, with subjective judgements around 'gut feel' and how client and consultant could work together still hold sway during the supplier selection process. The challenge for today's consulting firms is to systematically demonstrate WOK, WOW and WOB. 


\section{References}

ARMBRUSTER, T. 2006. The Economics and Sociology of Management Consulting, Cambridge, Cambridge University Press.

ARMBRÜSTER, T. \& GLÜCKLER, J. 2007. Organizational Change and the Economics of Management Consulting: A Response to Sorge and van Witteloostuijn. Organization Studies, 28, 1873-1885.

BRAUN, V. \& CLARKE, V. 2006. Using thematic analysis in psychology. Qualitative Research in Psychology, 3, 77-101.

BUONO, A. F. 2015. An Introduction to Management Consultancy. Academy of Management Learning \& Education, 14, 144-147.

CRAIG, D. \& BROOKS, R. 2006. Plundering the public sector : how New Labour are letting consultants run off with ${ }^{170}$ billion of our money, London, Constable.

ECONOMIST 2013. To the brainy, the spoils. The Economist. NY, NY: Economist.

FEACO 2017. Survey of the European Management Consultancy Market 2016/2017. Brussels: FEACO.

FURUSTEN, S. 2013. Commercialized professionalism on the field of management consulting. Journal of Organizational Change Management, 26, 265-285.

GAPPER, J. 2017. The curse of the consultants is spreading fast. Financial Times, 10th May.

HARI, J. 2010. The management consultancy scam. The Independent, 19th August.

HILL, J., ECKERD, S., WILSON, D. \& GREER, B. 2009. The effect of unethical behavior on trust in a buyer-supplier relationship: The mediating role of psychological contract violation. Journal of Operations Management, 27, 281-293.

HOPE, K. 2016. What does a management consultant do anyway? [Online]. BBC: BBC News. Available: http://www.bbc.co.uk/news/business-35220061 [Accessed 20th December 2017].

IOC. 2017. What is Consulting? [Online]. Online: Institute of Consultants. Available: (2017) http://www.iconsulting.org.uk/membership/what_consulting [Accessed 31-03-2017 2017].

KENNEDY 2010. The Consulting Market Size. email ed.: Kennedy Consulting Research and Advisory.

KIHN, M. 2005. House of Lies, New York, NY, Warner Business Books. 
KIPPING, M. 2002. Trapped in Their Wave: The Evolution of Management Consultancies. In: CLARK, T. \& FINCHAM, R. (eds.) Critical Consulting: New Perspectives on the Advice Management Industry. Oxford: Blackwell.

KIPPING, M. \& ENGWALL, L. (eds.) 2002. Management Consulting: Emergence and Dynamics of a Knowldege Industry, Oxford: OUP.

KIRKPATRICK, I., STURDY, A., NURIA, R. A., BLANCO-OLIVER, A. \& VERONESI, G. 2018. The impact of management consultants on public service efficiency. Policy and Politics.

KITAY, J. \& WRIGHT, C. 2007. From prophets to profits: The occupational rhetoric of management consultants. Human Relations, 60, 1613-1640.

LOWENDAHL, B., R. , REVANG, O. \& FOSSTENLOKKEN, S., M. 2001. Knowledge and value creation in professional service firms: A framework for analysis. Human Relations, 54, 911-931.

MALHOTRA, N. \& MORRIS, T. 2009. Heterogeneity in Professional Service Firms. Journal of Management Studies, 46, 895-922.

MARKETLINE 2013. Management and Market Consultancy in Europe. Marketline Industry Profile. Online: Marketline.

MARKETLINE 2016. Global Management \& Marketing Consultancy. MarketLine, a Datamonitor business.

MARKETLINE 2018. Management \& Marketing Consultancy in the United Kingdom. Marketline Industry Profile. London: Marketline.

MCA. 2017. The Consulting Industry [Online]. Management Consultancies Association: Online. Available: http://www.mca.org.uk/about-us/the-consulting-industry [Accessed 20th December 2017 2017].

MCKENNA, C., D. 2006. The World's Newest Profession. Management Consulting in the Twentieth Century., Cambridge, Cambridge University Press.

MUZIO, D., KIRKPATRICK, I. \& KIPPING, M. 2010. Professionalism without professions: The case of management consultancy in the UK. CERIC Working Paper Leeds: Centre for Employment Relations Innovation and Change, Leeds University Business School.

O'MAHONEY, J. \& MARKHAM, C. 2013. Management consultancy, Oxford, Oxford University Press.

OSBORN, R. F. 1956. GE and UNIVAC: Harnessing the High Speed Computers. Harvard Business Review, 32, 99-107.

PANETTI, M. 2007. Emerging Issues in Global Management Consulting. The Roland Berger Case. Symphonya. Emerging Issues in Management, 76-80. 
PATTERSON, P. G. 2000. A Contingency Approach to Modeling Satisfaction with Management Consulting Services. Journal of Service Research, 3, 138-153.

PLUNKETT, J. W. 2014. Consulting Industry Overview [Online]. Online: Plunkett Research Limited. Available: http://www.plunkettresearch.com/consulting-market-research/industrystatistics [Accessed 15th April 2014 2014].

SCHEIN, E. H. 1999. Process consultation revisited: Building the Helping Relationship, Reading (Mass.)); London, Addison-Wesley.

STURDY, A. 2011. Consultancy's Consequences? A Critical Assessment of Management Consultancy's Impact on Management. British Journal of Management, 22, 517-530.

STURDY, A., WYLIE, N. \& WRIGHT, C. 2013. Management Consultancy and Organizational Uncertainty: The case of internal consultancy. International Studies of Management and Organization, 43, 58-73.

TAYLOR, F. W. 1911. The Principles of Scientific Management, New York, Harper. 